\title{
UPAYA MENGEMBANGKAN MINAT MENULIS SISWA MELALUI GAWAI MENUJU NEW NORMAL
}

\author{
Purnami \\ SDN Karangtengah IV Wonosari \\ purnami_hanum@yahoo.co.id
}

\begin{abstract}
Abstrak
Tujuan dari penelitian ini adalah untuk mengetahui seberapa besar pengaruh gawai terhadap minat menulis siswa kelas VI, SDN Karangtengah IV menuju persiapan new normal. Dalam Penelitian ini digunakan pendekatan kualitatif deskriptif. Metode yang digunakan adalah melalui pemanfaatan gawai dalam kegiatan pembelajaran. Hasil penelitian menunjukkan bahwa dalam kegiatan menulis terutama pada saat pembelajaran dari rumah, siswa kelas VI SDN Karangtengah IV masih rendah. Namun, dalam penggunaan gawai dalam berkomunikasi sangat lancar. Hal tersebut yang mendorong untuk meneliti seberapa besar pengaruh gawai dalam menumbuhkan minat menulis siswa menuju persiapan new normal. Tahapan berupa perencanaan, pelaksanaan, dan evaluasi pembelajaran melalui pemanfaatan gawai dalam menumbuhkan minat menulis siswa. Siswa mendapatkan tugas melalui pembelajaran luring dan daring. Tugas tersebut berupa pemanfaatan video dan gambar melalui gawai yang mereka miliki, kemudian dikembangkan menjadi tugas tertulis. Kendala yang terjadi di lapangan adalah ada beberapa siswa yang tidak memiliki gawai sendiri, sehingga pengerjaan tugas menjadi tidak tepat waktu. Disamping itu, terkadang sulit mendapatkan sinyal. Efektifitas pemanfaatan gawai pada kegiatan pembelajaran adalah adanya peningkatan minat menulis pada siswa. Minat menulis tumbuh karena adanya rasa senang dengan media gawai tersebut. Dari rasa senang itulah timbul minat yang lebih terhadap tugas yang diberikan. Hasil akhir menunjukkan bahwa dengan pemanfaatan gawai dalam kegiatan pembelajaran, minat menulis di kelas VI pada SDN Karangtengah IV mengalami peningkatan.
\end{abstract}

\section{Kata Kunci: gawai, minat menulis, new normal}

\section{PENDAHULUAN}

Gawai merupakan kata lain dari bahasa Inggris gadget yaitu merupakan suatu alat yang mempunyai fungsi dan tujuan yang secara khusus dirancang lebih canggih yang didalamnya berupa teknologi yang memuat aplikasi dan informasi yang lengkap di dunia ini (Jarot Wijanarko, ayah ibu baik parenting digital, 2016). Semua orang telah menggunakan gawai ini setiap hari dan menjadi kebutuhan pokok dalam berkomunikasi. 
Gawai menjadi alat komunikasi yang semakin familiar semenjak adanya pandemi wabah covid 19. Hampir semua kegiatan terutama pembelajaran menggunakan alat tersebut. Gawai adalah alat canggih yang diciptakan memuat berbagai aplikasi yang dapat memberikan berbagai berita, media sosial, hobi serta hiburan (Widiawati, Sugiman, Edy, Pengaruh penggunaan gadget terhadap daya kembang anak, dalam seminar nasional multidisiplin ilmu, 2014). Peranannya semakin tampak ketika wabah covid 19 mendunia.

Penggunaan gawai pada beberapa tahun ini begitu penting. Pandemi covid 19 telah mempersempit ruang gerak manusia. Salah satu syarat yang bisa digunakan untuk tetap bisa berkomunikasi dengan dunia luar adalah dengan menggunakan gawai. Pesan singkat (sms) maupun WA dapat dilakukan tanpa ada batasan ruang. Pertemuan dilakukan melalui telepon dan video telepon. Hal ini juga berlaku pada kegiatan pembelajaran di masa pandemi tersebut. Siswa diberikan pembelajaran secara online menggunakan media gawai.

Setelah pelaksanaan kegiatan pembelajaran kombinasi dalam jaringan (daring/online) dan diluar jaringan/tatap muka (luring) terdapat kenyataan bahwa siswa mengalami dua hal yang berlawanan. Kemampuan dalam menggunakan media gawai lebih cenderung menarik dalam kegiatan berkabar dalam bentuk percakapan WA baik itu pribadi maupun berkelompok/grup. Namun, disisi lain, kemampuan siswa dalam kegiatan menulis terutama menulis secara manual menggunakan tulisan tangan menjadi menurun. Hal tersebut dapat terlihat dari hasil yang dikumpulkan saat mengerjakan tugas dalam bentuk tulisan tidaklah semakin meningkat, tetapi mengalami penurunan.

Berbanding terbalik dengan keadaan mengenai minat menulis siswa, penggunaan gawai semakin diminati. Gawai tidak dipergunakan untuk menyelesaikan tugas menulis, tetapi mereka menggunakan untuk kegiatan berkegiatan di media sosial seperti bermain tik-tok, membuka instagram, berkomunikasi lewat WA, membuka facebook ataupun bermain game online. Hal tersebut menarik untuk diteliti, karena adanya hubungan yang erat antara gawai dengan siswa yaitu bahwa ternyata gawai semakin diminati sedangkan minat menulis siswa menurun. 
Berdasarkan pada kenyataan di atas, maka timbul suatu upaya untuk kembali mengembangkan minat siswa untuk lebih tertarik terhadap kegiatan menulis dengan cara mempergunakan gawai sebagai alat untuk mengembangkannya. Pengembangan apapun termasuk kegiatan menulis perlu adanya motivasi. Siswa dimotivasi untuk kembali tertarik pada kegiatan menulis melalui pemanfaatan gawai. Hal itu bertujuan supaya pembelajaran terutama pada kegiatan menulis berjalan dengan lancar.

Senada dengan ahli psikologi yang menjelaskan bahwa motivasi berfungsi sebagai pendorong, penggerak, serta sebagai pengarah perbuatan, (Haryu Islamudin, 2012:264). Motivasi dapat berupa dorongan dari dalam diri dan dorongan dari luar. Penggunaan gawai diharapkan mampu mendorong siswa melakukan kegiatan dengan dua cara tersebut. Penggunaan gawai sebagai pendorong dari dalam diri berupa keinginan diakibatkan dari keinginan dalam pemanfaatan gawai, yang kedua dorongan dari luar yaitu pengaruh yang ditimbulkan dari teman maupun guru.

Motivasi dalam kegiatan belajar adalah power pendorong bagi siswa untuk menciptakan potensi-potensi yang ada pada dirinya dan potensi-potensi di luar dirinya untuk mencapai tujuan. Motivasi belajar itulah yang nanti akan digunakan sebagai pijakan dalam medorong terciptanya minat menulis dalam upaya memasuki era new normal. Motivasi dapat berupa motivasi dari dalam diri anak dan motivasi dari luar. Diharapkan melalui gawai yang dimiliki anak, anak dapat termotivasi melalui dirinya sendiri.

Minat menulis sendiri adalah suatu upaya untuk meningkatkan kemauan anak dalam kegiatan menulis. Menulis adalah salah satu kegiatan aktif dalam berbahasa. Menggunakan kemampuan motorik dan pengetahuan. Kedua kemampuan itu harus berimbang sehingga yang diharapkan pada hasil akhir adalah anak mampu menuangkan kreatifitasnya dalam bentuk tulisan.

Minat dapat diartikan sebagai suatu keinginan yang mendorong seseorang melakukan sesuatu. Minat menulis adalah suatu keinginan untuk mengungkapkan sesuatu tidak hanya dalam simbol semata tetapi juga dalam bentuk gambar (Soemarmo Markam, 1989:112). Keinginan tersebut dapat lancar menjadi sebuah 
kenyataan apabila dilakukan suatu tindakan yang berkenaan dengan kegiatan yang dilaksanakan tersebut.

Menulis dapat dilakukan dengan kegiatan menjabarkan ide-ide yang ada dalam pikiran menjadi simbol-simbol sederhana yang kemudian dipilah-pilahkan ke dalam bentuk tulisan sederhana. Tulisan-tulisan tersebut kemudian dirangkai menjadi kata kemudian kalimat yang pada akhirnya bermuara di paragraf. Paragraf inilah yang dapat mengungkap gagasan-gagasan serta ide-ide yang tersimpan pada semua siswa.

Menulis dapat diartikan sebagai bahasa jiwa. Bahasa yang dituangkan dalam bentuk tulisan. Gagasan yang ada dituangkan dalam tulisan yang bermakna. Gagasan yang dituangkan dalam aktivitas melalui media (Nurgiyantoro:2001). Media yang dimaksud adalah bisa media cetak berupa tulisan pada lembaran kertas maupun media elektronik berupa tulisan pada media elektronika. Tulisan yang dibuat berdasarkan pada usia siswa tersebut yang memberikan dampak yang positif bagi perkembangannya.

Menulis adalah kegiatan yang produktif yang memberikan beberapa manfaat diantaranya untuk meningkatkan kecerdasan, mengembangkan inisiatif dan kreatifitas, menumbuhkan keberanian anak, untuk mendorong kemauan dan keterampilan dalam mengumpulkan informasi (Suparno dan Muhamad, 2007:14). Kegiatan itu yang mendorong siswa berkreasi terhadap pengetahuannya masingmasing. Kreatifitas menumbuhkan kemampuan dalam mengasah otak, sehingga mampu bersaing dalam pembelajaran di sekolah maupun dalam kehidupan nyata bermasyarakat.

Secara umum tujuan menulis adalah dapat mempengaruhi keyakinan pada pembaca, memberikan penanaman pemahaman pada pembaca, merangsang memroses berpikir membaca, menghibur dan menyenangkan pembaca, memberitahu dan memotivasi pembaca (Syafie'e, 1988:68). Hal tersebut memberikan makna bahwa menulis bisa menumbuhkan keahlian. Keahlian dalam membaca situasi, menuangkannya dalam bentuk simbol-simbol dalam bentuk rangkaian huruf maupun dalam bentuk penggambaran baik berupa gambar maupun grafik, sehingga orang lain paham terhadap yang disampaikan. 
Kemampuan menulis, sangat berpengaruh terhadap kemajuan berbahasa siswa. Siswa akan mampu menghasilkan sesuatu. Menulis merupakan ragam bahasa aktif. Hasil akhir dari kegiatan menulis diharapkan mampu memperkuat pengetahuan anak dalam rangka memasuki pembelajaran new normal. Ketika siswa mengetahui sesuatu, dan terekam di otak, maka gambaran yang mereka ketahui itu dapat mereka tuliskan menjadi kata-kata sebagai penyampai pesan kepada orang lain.

Pandemi virus 19 sangat mempersempit gerak manusia. Salah satunya dalam bidang ilmu pengetahuan. Pengetahuan menjadi terhambat perkembagannya terutama pada jenjang pendidikan dasar. Hal ini jika tidak diimbangi dengan upaya yang kuat, mengakibatkan pengetahuan menjadi berhenti. Pengetahuan dapat ditingkatkan melalui pemahaman peserta didik, dengan cara memperkuat literasi mereka terutama dalam kegiatan menulis. Salah satu upaya yang dilakukan adalah melatih mereka untuk dapat menuangkan ideide kreatif mereka untuk didokumentasikan dalam bentuk tulisan dari yang paling sederhana. Hal tersebut dilakukan, agar nantinya siswa dapat terus melanjutkan pendidikan meskipun baru dalam tahap persiapan pembelajaran menuju new normal.

Dalam perkembangan pandemi virus 19, kalimat new normal sering kita dengar. Dalam New normal adalah kita berada pada sebuah perubahan dalam budaya hidup yang diselenggarakan pemerintah agar masyarakat dapat terbiasa dengan tatanan hidup normal baru dalam rangka menghadapi penyebaran virus corona (https://www.wartaekonomi.co.id).

Pembelajaran yang dilakukan pada masa perubahan perilaku baru ini diharapkan dapat menyesuaikan dengan keadaan perkembangan siswa. Peran aktif guru sebagai fasilitator sangat berpengaruh. Salah satu yang digunakan guru untuk menyikapi tantangan era new normal adalah kemampuan beradaptasi siswa dalam kaitannya dengan pemanfaatan teknologi yang paling familiar dengan mereka.

Menurut Ketua TIM Pakar Gugus Tugas, new normal diartikan sebagai perubahan perilaku dalam rangka untuk tetap menjalankan kegiatan normal namun dengan tetap mematuhi protokal kesehatan dalam rangka pencegahan terjadinya penyebaran covid 19 (https://www.kompas.com). 
Tantangan yang ada adalah ketidaksiapan siswa dalam memasuki era new normal terutama dalam kegiatan berbahasa dalam ragam menulis. Jika ini tidak segera teratasi, masalah yang timbul akan semakin besar dan dampak akhirnya akan terjadi kemunduran kemajuan pengetahuan. Oleh karenanya perlu diadakan suatu upaya dengan menggunakan media yang paling dekat dengan anak untuk mewujudkan impian bersama, menciptakan kesiapan anak terutama dalam kegiatan menulis menuju era new normal.

\section{METODE/ CARA}

Subjek penelitian ini adalah siswa kelas VI SDN Karangtengah IV tahun pelajaran 2020/ 2021 yang berjumlah 26 anak. Kegiatan dalam penentuan subjek penelitian, memerlukan survei pendahuluan. Objek dalam penelitian ini adalah pemanfaatan gawai untuk menumbuhkan minat menulis dalam menghadapi pembelajaran new normal.

Penelitian ini dilaksanakan dengan mengambil obyek kelas VI pada SDN Karangtengah IV. Alamat sekolah terletak di Dusun Kedung I, Karangtengah, Wonosari, Gunungkidul, Yogyakarta. Siswa-siswa kelas VI berasal dari sekitar sekolah. Mata pencaharian wali murid adalah buruh serabutan, petani, dan sebagian yang lain berdagang.

Pada semester kedua yang dimulai pada setiap bulan Januari, siswa telah dikondisikan untuk mempersiapkan diri menghadapai penilaian dasar /assesmen. Penilaian tersebut dikenal dengan istilah Asesmen Standar Penilaian Daerah atau disingkat dengan ASPD. ASPD sendiri merupakan ujian untuk mengukur kemampuan siswa dan digunakan sebagai salah satu sarana mendaftar ke jenjang pendidikan selanjutnya (SMP) jalur prestasi, namun tidak digunakan sebagai penentu kelulusan.

Di Kabupaten Gunungkidul pada pendidikan dasar khususnya, sudah sejak tahun 2019 direncanakan ujian dengan CBT menggunakan sarana komputer dan dilaksanakan secara online. Namun, pelaksanaannya tertunda karena adanya pandemi covid 19 yang menyebar ke seluruh dunia pada tahun 2020. Kegiatan ASPD berbasis CBT akhirnya dilanjutkan pada tahun pelajaran 2020/2021. Di SDN Karangtengah IV sendiri termasuk sekolah pinggiran di Wilayah Wonosari 
yang belum memiliki sarana komputer, sehingga rencana ujian ASPD dilakukan menggunakan gawai milik siswa.

Pembelajaran tatap muka selama pandemi hingga bulan Januari belum terlaksana secara efektif sehingga pembelajaran tetap dilaksanakan dengan dua kegiatan luring (pertemuan tatap muka) dan daring (dalam jaringan/online). Selama kegiatan pembelajaran secara luring, ditemui kenyataan bahwa kemauan anak untuk menulis menurun. Hal ini terlihat pada hasil pekerjaan anak yang dilaksanakan pada waktu pertemuan tatap muka hasilnya menurun.

Namun ketika siswa berkomunikasi dengan teman menggunakan gawai, terlihat mereka sangat lancar dalam menggunakan gawai tersebut. Dari kenyataan itu, peneliti mencoba untuk melaksanakan penelitian dengan mempergunakan gawai dalam upaya untuk mendorong minat menulis siswa. Dengan memanfaatkan hal yang menarik perhatian siswa tersebut, diharapkan hasil yang dicapai dapat maksimal.

Penelitian dilaksanakan pada bulan Januari 2021 sampai dengan Maret 2021. Dalam penelitian ini digunakan pendekatan kualitatif deskriptif. Kehadiran peneliti penting, hal ini berkaitan dengan fungsi utama peneliti adalah sebagai instrument utama sekaligus berperan sebagai pengumpul data yang juga mengamati atau mengadakan penelitian langsung pada obyek. Peneliti berhubungan langsung dengan siswa sebagai obyek penelitian. Penggunaan teknik pengumpulan tersebut data adalah observasi, wawancara mendalam, studi dokumentasi dan trianggulasi. Peneliti menggunakan metode teknik purposive sampling atau menentukan contoh dengan pertimbangan tertentu agar data yang diperoleh lebih representatif (Sugiyono, 2014:32). Teknik analisis data mengambil Miles dan Huberman sedangkan aktivitas dalam analisis data berupa reduksi data, display (penyajian data), dan verifikasi. Semua dilaksanakan dengan teliti sehingga penelitian dapat memperoleh hasil yang baik.

\section{HASIL PENELITIAN DAN PEMBAHASAN}

Berdasarkan analisis kualitatif deskriptif melalui wawancara, observasi dan studi dokumentasi yang telah dilaksanakan tentang pemanfaatan gawai sebagai salah satu upaya yang diharapkan mampu memotivasi siswa, sehingga mampu 
menimbulkan minat menulis siswa kelas VI pada SD Negeri Karangtengah IV, telah dilaksanakan dengan rinciannya sebagai berikut:

1. Kegiatan Perencanaan

Kegiatan perencanaan pembelajaran berfokus kepada pemilihan materi yang akan digunakan. Materi yang dipersiapkan pada penelitian ini adalah yang berkaitan dengan persiapan ujian ASPD mata pelajaran Bahasa Indonesia dengan fokus pada kegiatan menulis. Perencanaan tersebut dituangkan ke dalam Rencana Pembelajaran yang lengkap sampai dengan penilaian.

Setelah kegiatan pembuatan rencana pembelajaran, kegiatan dilanjutkan dengan pemilahan materi berdasarkan kegiatan yang akan dilaksanakan selama 3 bulan. Materi dipilah menjadi 4. Minggu pertama menulis sastra dalam bentuk puisi. Minggu kedua menulis kembali isi cerita. Minggu ketiga merefleksi kegiatan yang sudah dilaksanakan pada minggu pertama dan minggu kedua. Minggu ke empat mengunkapkan dengan kalimat mengenai gambar yang dilihat, dan minggu kelima menuliskan pengalaman yang dirasakan saat mengerjakan tugas dari minggu pertama hingga minggu keempat.

2. Kegiatan Pelaksanaan

Pelaksanaan pembelajaran minggu pertama diawali dengan pembelajaran secara luring/ tatap muka, durasi pembelajaran selama satu jam. Sehari dilaksanakan sebanyak dua sesi dengan jumlah siswa tiap sesi sejumlah 13 anak. Pembelajaran dilaksanakan dengan mematuhi prosedur kesehatan pencegahan covid 19, dengan memakai masker dan mencuci tangan serta cek suhu tubuh sebelum memasuki kelas.

Pembelajaran dimulai dengan memberikan materi dengan tema peduli lingkungan, dengan tujuan akhir menciptakan masyarakat yang sejahtera sebagai wujud kepedulian lingkungan. Siswa terlebih dahulu diberikan penjelasan mengenai apa itu sikap peduli terhadap lingkungan. Diberi contoh kegiatan nyata yang ada dilingkungan sekolah. Kemudian, siswa diberikan tugas secara daring di rumah, untuk mencari contoh berupa gambar atau video kegiatan peduli terhadap lingkungan itu seperti apa. Kemudian siswa diberikan tugas membuat tulisan dalam bentuk puisi, dengan judul bebas bertemakan lingkungan. Tulisan tersebut diberi tugas secara online dengan mengetikkan puisi melalui tulisan WA dan 
portofolio dengan menggunakan tulisan tangan. Tugas portofolio diberikan selama seminggu dan dikumpulkan pada minggu kedua.

Pelaksanaan pada minggu kedua, para siswa diminta mengumpulkan portofolio hasil dari tugas pada minggu pertama. Kemudian pada waktu luring, siswa diminta untuk mengamati video bertemakan lingkungan, video berupa kegiatan keluarga bersama-sama membersihkan lingkungan rumah, serta video mengenai kegiatan membersihkan lingkungan sekitar. Setelah proses pengamatan selesai, siswa diberi tugas untuk menceritakan kembali apa yang mereka lihat pada kedua video tersebut. Agar pengamatan lebih jelas, video akan dikirimkan ke gawai mereka melalui WA grup siswa. Sama seperti pada kegiatan minggu pertama, siswa diminta mengerjakan dengan dua metode, online dan berupa portofolio. Hasil online segera dikirimkan setelah selesai pembuatan, sedangkan hasil portofolio berupa tulisan dalam kertas akan dikumpulkan pada luring minggu ke tiga.

Kegiatan luring pada pertemuan minggu ketiga, siswa mengumpulkan tugas portofolio kemudian secara bersama-sama dengan guru mengamati dan kemudian menyampaikan hasil yang sudah dikumpulkan berupa tulisan tangan dan kiriman online yang dikirim melalui WA. Anak diberikan kesempatan untuk menceritakan mengenai kesulitan dan hambatan yang dialami selama pengerjaan tugas menulis yang diberikan oleh guru. Setelah dicatat oleh guru, kemudian guru memberikan arahan bagaimana sebaiknya dalam membuat tulisan dengan memanfaatkan gawai agar lebih mudah dan menyenangkan bagi siswa. Selanjutnya, siswa diberikan tugas menuliskan hambatan yang dialami untuk dilaksanakan pada minggu keempat. Tugas masih sama dengan dua kegiatan, berupa tulisan online lewat WA dan tulisan portofolio.

Pertemuan minggu keempat dilaksanakan dengan kegiatan mengumpulkan hasil portofolio yang telah diberikan pada siswa pada minggu ketiga. Kemudian anak diminta untuk mengamati gambar tentang lingkungan yang bersih dan lingkungan yang kotor. Setelah itu, siswa diminta untuk membuat cerita tentang apa yang mereka lihat paada gambar tersebut. Untuk lebih jelasnya, gambar tersebut dikirimkan melalui gawai siswa dengan mengirimkan gambar pada WA grup. 
Pada minggu kelima, kegiatan yang dilakukan setelah semua tugas dikumpulkan, kemudian kembali dilakukan refleksi terhadap pengerjaan mereka. Kemudian setelah selesai merefleksi, seluruh tugas dari minggu pertama hingga minggu keempat dikembalikan ke siswa. Kemudian, untuk tugas selanjutnya, siswa diminta menulis dengan bahasanya sendiri mengenai kesulitan yang dialami selama mengerjakan tugas menulisnya dari minggu pertama hingga minggu keempat.

Dari hasil pekerjaan yang dikumpulkan siswa baik secara luring berupa portofolio dan daring berupa kiriman melalui WA, dapat disimpulkan bahwa pekerjaan yang mereka lakukan berbeda antara pekerjaan pertama sampai dengan pekerjaan keempat. Berbanding terbalik antara hasil portofolio dengan secara online. Perbedaan tersebut terlihat pada panjang pendek tulisan antara penulisan luring dan daring. Tampak terlihat bahwa pekerjaan yang menampilkan jumlah kalimat yang sedikit lebih mudah dilaksanakan melalui tulisan langsung WA, namun tulisan yang panjang seperti bercerita lebih lengkap dan jelas dengan tulisan tangan.

Pada pertemuan minggu keenam, siswa menceritakan kendala yang mereka alami selama mengerjakan tugas menulis. Analisa sama, yaitu mereka menemukan kesulitan dalam mengerjakan secara online melalui tulisan langsung pada WA. Tetapi pada saat tugas yang mereka kerjakan lebih pendek, mereka lebih senang jika pekerjaan dilakukan secara langsung pada gawai mereka. Tetapi seluruh siswa mengatakan senang dengan tugas menulis yang diberikan, karena mereka langsung bisa menuliskan apa yang mereka pikirkan dengan bantuan gawai yang mereka punya. Mereka tampak sangat berantusias untuk mendapatkan tugas yang lain, yang masih berkaitan atau dengan menggunakan gawai yang mereka miliki.

Siswa mengalami kesulitan dalam kegiatan menulis dengan cara langsung/ online dengan portofolio pada kertas, maka guru memberikan solusi kepada siswa untuk mengerjakan tugas tersebut menyalin di kertas folio dengan tulisan yang rapi, kemudian tulisan tersebut mereka foto dan dapat dikirimkan melalui grup WA. 
Pada kegiatan akhir penelitian, guru melakukan pengamatan terhadap perubahan minat siswa terhadap minat menulisnya. Hal ini senada dengan pendapat ahli psikologi bahwa motivasi mempunyai fungsi dalam proses belajar sebagai pendorong, penggerak perbuatan, serta sebagai pengarah perbuatan, (Haryu Islamudin, 2012:264). Akhirnya dapat diperoleh hasil bahwa selama pelaksanaan pembelajaran menggunakan pemanfaatan gawai dapat meningkatkan minat menulis pada siswa, meskipun tulisan tersebut relatif panjang. Siswa lebih berminat menuangkan apa yang mereka fikirkan dalam bentuk tulisan, baik secara langsung di gawai maupun secara tertulis dengan tangan. Hal ini nantinya sangat berpengaruh terhadap perkembangan kebahasaan mereka dalam menghadapi pembelajaran di pembelajaran new normal yang akan datang.

\section{Kegiatan evaluasi}

Tahap selanjutnya adalah mengelola pembelajaran berupa evaluasi. Peranan gawai dalam menumbuhkan motivasi menulis pada siswa perlu dievaluasi. Senada dengan tulisan Gultom (2014:30) yang menyatakan bahwa penilaian adalah proses evaluasi dalam mengukur kinerja-kinerja, prestasi, motivasi, dan sikap-sikap siswa pada aktivitas pembelajaran.

Pelaksanaan evaluasi dari pembelajaran menggunakan gawai sebagai sarana meningkatkan minat menulis ini dilakukan melalui beberapa penilaian. Penilaian itu diambil dari pengamatan dan hasil pekerjaan para siswa. Penilaian diambil dari hasil tiap kali siswa melakukan mengerjakan tugas menulis yang mereka lakukan. Meliputi kegiatan menulis sastra berupa puisi, menceritakan kembali apa yang mereka lihat baik lewat gambar maupun video. Pengamatan dilaksanakan melalui kegiatan pengamatan terhadap peningkatan kemampuan siswa dalam bentuk tulisan yang mereka kumpulkan baik secara luring maupun daring.

4. Kendala dalam pemanfaatan gawai terhadap minat menulis siswa menuju era new normal

Dalam pelaksanaan pemanfaatan gawai dalam upaya menumbuhkan minat menulis siswa menuju persiapan new normal pada kelas VI di SD Negeri Karangtengah IV terdapat beberapa kendala. Kendala yang ada diantaranya tidak semua siswa memiliki gawai sendiri. Mereka menggunakan satu gawai untuk 
seluruh keluarga, sehingga pengumpulan pekerjaan menjadi lebih lama. Terkadang gawai dibawa bekerja oleh orang tua, sehingga waktu yang mereka miliki terbatas.

Kendala yang selanjutnya adalah terletak pada sinyal. Karena lokasi SDN Karangtengah IV terletak di pinggiran, terkadang sinyal berpengaruh terhadap pengiriman tugas yang diberikan kepada anak. Jika letak rumah siswa menjangkau lebih baik sinyalnya, maka pengiriman tugas mudah. Tetapi bagi siswa yang jauh jangkauan sinyalnya, pengiriman jawaban menjadi tertunda.

\section{Efektifitas}

Dalam pelaksanaan pemanfaatan gawai terhadap minat menulis siswa menuju era new normal, tujuan akhirnya adalah adanya efektifitas. Hasil akhir dari kegiatan pembelajaran tersebut adalah adanya peningkatan motivasi yang mendorong pada minat menulis siswa di SD Negeri Karangtengah IV.

Hasil dari meningkatnya minat menulis pada anak terlihat pada kemauan anak untuk menulis tanpa paksaan dan dengan senang hari menggunakan gawai sehingga pada akhir kegiatan ASPD mendapatkan nilai yang maksimal dengan kemampuan menulis mereka. Hal ini berpengaruh pula terhadap persiapan pembelajaran menuju era new normal.

Diperoleh juga bahwa dengan pemanfaatan gawai yang mereka miliki, mereka bebas menuangkan ide-ide yang mereka miliki tanpa paksaan. Jika kegiatan dilaksanakan melalui motivasi dari dalam diri, maka hasil yang didapat diharapkan dapat maksimal, sesuai dengan perkembangan siswa. Mereka pun akan merasa puas dengan hasil kerjanya.

\section{SIMPULAN}

Berdasarkan hasil penelitian diperoleh hasil bahwa pemanfaatan gawai dalam memberikan sarana menumbuhkan minat menulis pada siswa memiliki pengaruh yang signifikan. Jika sebelumnya minat menulis pada siswa rendah, setelah menggunakan sarana gawai sebagai media pembelajaran, kemauan dan minat siswa terhadap kegiatan menulis semakin meningkat.

Peranan guru adalah sebagai fasilitator memberikan motivasi melalui pendampingan yang diberikan selama kegiatan pembelajaran baik itu secara luring ketika siswa belajara di sekolah maupun saat pengerjaan secara daring, ketika 
siswa melakukan pembelajaran dalam jaringan di rumah menggunakan media gawai. Hasil apapun yang siswa kerjakan dinilai baik. Hanya saja misalnya belum sempurna diberikan arahan setelah refleksi sehingga perbaikan selanjutnya dapat menghasilkan karya yang lebih baik dari sebelumnya.

Peningkatan minat menulis pada siswa ini dapat dilihat dari semakin baiknya tulisan yang mereka kumpulkan dalam bentuk portofolio maupun dengan cara langsung menuliskan pada tulisan WA. Motivasi terhadap siswa ini perlu dilakukan agar tulisan mereka pada akhirnya menjadi semakin baik. Meskipun ada beberapa kendala, namun jika dilaksanakan dengan penuh motivasi, kendala tersebut dapat diminimalkan.

Tujuan akhir dari penelitian ini adalah meningkatnya kemampuan berbahasa anak terutama dalam kegiatan menulis. Menulis yang dimaksudkan adalah kemampuan siswa dalam menuangkan gagasan dan ide mereka kedalam ragam bahasa tulis yang bisa dimengerti oleh pembaca. Tujuannya adalah siswa mampu bersaing untuk memasuki pembelajaran di era new normal.

Akhirnya pada penelitian ini dapat disimpulkan bahwa pemanfaatan gawai dapat menumbuhkan minat menulis pada siswa kelas VI SDN Karangtengah IV, sehingga tujuan akhir dapat meningkatkan hasil dalam pengerjaan ASPD sehingga dapat melanjutkan pendidikan di jenjang yang lebih tinggi menuju persiapan new normal. Dampak akhir adalah adanya peningkatan kemauan dan kemampuan siswa untuk menulis sebagai salah satu ukuran keberhasilannya. Siswa menjadi semakin siap menghadapi kelanjutan pembelajaran di era new normal.

\section{DAFTAR PUSTAKA}

Gultom. (2013). Materi Pelatihan Guru: Implementasi Kurikulum 2013, Jakarta: Pendidikan dan Kebudayaan.

Haryu.Islamudin. (2012). Psikologi Pendidikan, Yogyakarta: Pustaka Belajar.

Dandy Bayu Bramasta (2020). Mengenal Apa Itu New Normal di Tengah Pandemi Corona, https://www.kompas.com

Fajriya Anindya Utami (2020). Apa Itu New Normal?, https://www.wartaekonomi.co.id.

Jarot.Wijanarko. (2016). Bapak Ibu Baik Parenting Era Digital, Jakarta Selatan: Keluarga Indonesia Bahagia. 
Nurgiyantoro.(2001). Penilaian dalam Pengajaran Bahasa dan Sastra,Yogyakarta: BPFE.

Soemarno.Markam. (1989). Neurologi Praktis, Jakarta : Kalbe Farma.

Sugiyono. (2014). Metode Penelitian Pendidikan Pendekatan Kuantitatif, Kualitatif, dan $R \& D$. Bandung: Alfabeta

Suparno.Yunuf.Muhamad(2007). Keterampilan Dasar Menulis, Jakarta: Universitas terbuka.

Syafie.ie (1988). Retorika dalam Menulis. Jakarta: P2LPTK Depdikbud.

Widiawati.Sugiman.Edy. (2014). Pengaruh Penggunaan Gadget Terhadap Daya Kembang Anak ( E-journal), Jakarta: Universitas Budi Luhur. 